\title{
Comparison of Oxidant-Antioxidant Status in Patients with Vitiligo and Healthy Population.
} Agrawal $S,{ }^{1}$ Kumar A, ${ }^{1}$ Dhali TK, ${ }^{2}$ Majhi SK ${ }^{3}$

\author{
${ }^{1}$ Department of Dermatology \& Venereology \\ B.P. Koirala Institute of Health Sciences \\ Dharan, Nepal \\ ${ }^{2}$ Department of Dermatology \& Venereology \\ ESIC PGIMSR, Basaidarapur, New Delhi \\ ${ }^{3}$ Department of Biochemistry \\ B. P. Koirala Institute of Health Sciences \\ Dharan, Nepal
}

\section{Corresponding Author}

Sudha Agrawal

Department of Dermatology \& Venereology

B.P. Koirala Institute of Health Sciences

Dharan, Nepal

E-Mail: sudha92@yahoo.com

\section{Citation}

Agrawal S, Kumar A, Dhali TK, Majhi SK. Comparison of Oxidant-Antioxidant Status in Patients with Vitiligo and Healthy Population. Kathmandu Univ Med J 2014;46(2):132-6.

\section{ABSTRACT}

\section{Background}

Vitiligo is a well-recognized pigmentary disorder of the skin and /or mucous membrane characterized by circumscribed ivory or chalky white macules devoid of identifiable melanocytes. The pathogenesis of vitiligo is complex and still not well understood. According to autocytotoxic hypothesis, oxidative stress has been suggested to be the initial pathogenic event in melanocyte degeneration. The role of free radicals and oxidative damage in the pathophysiology of vitiligo has been documented in recent studies.

\section{Objective}

To evaluate the role of oxidative stress in patients with vitiligo and of healthy controls by measuring levels of the oxidant malondialdehyde (MDA) and antioxidants vitamin $C$ and vitamin $E$ in serum and catalase (CAT) in erythrocytes.

\section{Method}

A total of 80 clinically diagnosed cases of vitiligo and 80 control subjects were included in the study to assess the activity of MDA, vitamin C and vitamin E in serum and CAT in erythrocytes of patients and controls by using the spectrophotometric assay.

\section{Result}

There was statistically significant increase in the levels of MDA in patients with vitiligo compared to the control group $(p<0.001)$. No significant difference was found in the levels of vitamin $C(p=0.411)$ and vitamin $E(p=0.771)$ between the patients with vitiligo and control group. The levels of CAT in the vitiligo patients were found to be significantly lower than those of controls $(p<0.001)$.

\section{Conclusion}

Increased oxidative stress and decreased catalase have been observed in vitiligo patients and the data suggesting that the free radicals may be involved in the destruction of melanocytes or dysregulation of melanogenesis.

\section{KEY WORDS}

Antioxidants, oxidants, vitiligo 


\section{INTRODUCTION}

Vitiligo is a well-recognized pigmentary disorder of the skin and/or mucous membrane, characterized by circumscribed ivory or chalky white macules of different size and shape that affects approximately $0.1-2 \%$ of world population. ${ }^{1}$ It can develop at any age, but $50 \%$ of cases appear before the age of 20 years regardless of sex or racial background. ${ }^{1,}$ 2 The inherited predisposition to the disease has been observed in about $30 \%-40 \%$ of the affected persons. ${ }^{3}$

Vitiligo is essentially a cosmetic problem. It often causes social and emotional consequences including low selfesteem, social anxiety, depression, stigmatization and in extreme cases, rejection by those around them. ${ }^{4}$ The pathogenesis of vitiligo is complex and still not well understood. The question posed is about "vitiligo pathogenesis": is it due to autoimmune mechanism, genetic defect, excessive reactive oxygen species (ROS), calcium imbalance, or what else. ${ }^{5}$ According to autocytotoxic hypothesis, oxidative stress has been suggested to be the initial pathogenic event in melanocyte degeneration. ${ }^{6}$ The role of free radicals and oxidative damage in the pathophysiology of vitiligo has been documented in recent studies. $^{3,6-11}$

The aim of the present study was to evaluate the role of oxidative stress playing in patients with vitiligo and of healthy controls by measuring levels of the oxidant malondialdehyde (MDA) and antioxidants vitamin $C$ and vitamin $\mathrm{E}$ in serum and catalase (CAT) in erythrocytes.

\section{METHOD}

\section{Patients and controls}

Eighty clinically diagnosed cases of vitiligo attending the dermatology outpatient department at B.P. Koirala Institute of Health Sciences (BPKIHS), Dharan were assessed for oxidants and antioxidants status in their blood. Patients less than 15 years age, history of the use of any topical or systemic treatment for vitiligo in the previous month, active and passive smokers, history of intake of vitamins and anti-inflammatory drugs in the previous month, history of chronic liver, kidney or cardiovascular disease, history of excessive exercise apart from daily life activities, concomitant any dermatological diseases and pregnancy were excluded from the study. The active and stable phase of vitiligo are defined on the basis of the progression or appearance of new lesions in the last 6 months and the absence of new lesions or their progression in the last 6 months, respectively. The control group in the study consisted of 80 age-matched healthy consenting volunteers. Informed consent was taken from all the subjects enrolled in the study and the study was approved by the Institutional Ethical Review Board.

Measurement of oxidants-antioxidants in vitiligo and healthy population
Six milliliters of blood was collected from the cubital median vein of the patients and controls to assess the activity of MDA, vitamin C and vitamin in serum; and CAT in erythrocytes by using the spectrophotometric assay. ${ }^{12-15}$

\section{Statistical analysis}

The measured values were expressed as mean and standard deviation (SD) and were compared by the Student's t test for normal distributed variables, Mann Whitney $U$ test for non-normal distributed variables and ANOVA test to determine significant differences in various biochemical activities between progressive and stable vitiligo patients and healthy controls. $p$ value of $<0.05$ was considered to be statistically significant.

\section{RESULT}

The mean age of vitiligo patients and healthy population was $32.66 \pm 16.82$ years and $32.61 \pm 15.63$ years respectively. There were 36 (45\%) males and 44 (55\%) females among the healthy population, and 39 (48\%) males and 41 (52\%) females among the vitiligo patients. Although, majority of the patients i.e., 52 (65\%) had Fitzpatrick skin phototype IV, 26 (32.5\%) had skin phototype III and 2 (2.5\%) of the patients had skin phototype $\mathrm{V}$ respectively. The mean duration of disease was $8.76 \pm 8.51$ years. Majority $(88.7 \%)$ of the patients had body surface area involvement of less than $25 \%$ and only 4 patients (5\%) had body surface area involvement of more than $50 \%$. The mean percent body surface area involvement was $15.18 \pm 20 \%$. Most of the patients had gradual progression of the lesion and Koebner phenomenon was present in 28 (35\%) patients. The most common type of vitiligo was vitiligo vulgaris, observed in 70 (82.7\%) patients, followed by 3 (5.8\%) each focal vitiligo, acrofacial vitiligo and segmental vitiligo. There was only 1 patient having vitiligo universalis (body surface area $>80 \%$ ).

\section{Comparison of oxidant-antioxidant status between vitiligo patients and healthy population}

Table 1 depicts the comparison of oxidant-antioxidant status between vitiligo patients and healthy population. The value of malondialdehyde (MDA) was $7.99 \pm 2.30$ $\mathrm{nmol} / \mathrm{L}$ and $6.13 \pm 1.24 \mathrm{nmol} / \mathrm{L}$ among the vitiligo patients and healthy population respectively. MDA was found to be significantly higher among the vitiligo patients as compared to healthy population with a $\mathrm{p}$ value of $<0.001$.

The value of vitamin C was $0.65 \pm 0.15 \mathrm{mg} / \mathrm{dl}$ and $0.63 \pm 0.14$ $\mathrm{mg} / \mathrm{dl}$ among the vitiligo patients and healthy population respectively. There was no statistically significant difference between these two groups. The value of vitamin $E$ was $0.67 \pm 0.22 \mathrm{mg} / \mathrm{dl}$ in vitiligo patients, while the value of vitamin $\mathrm{E}$ was $0.67 \pm 0.15 \mathrm{mg} / \mathrm{dl}$ among healthy population respectively. Statistical comparison between the groups did not show significant difference in vitamin E level.

Among the vitiligo patients and healthy population, the value of catalase (CAT) was $53.93 \pm 24.77 \mathrm{IU} / \mathrm{gm} \mathrm{Hb}$ and 
Table 1. Comparison of oxidant/antioxidant status of healthy population and vitiligo patients

\begin{tabular}{|c|c|c|c|c|}
\hline $\begin{array}{l}\text { PARAM- } \\
\text { ETERS }\end{array}$ & $\begin{array}{l}\text { VITILIGO PATIENTS } \\
\text { [mean } \pm \text { SD }(\mathrm{CI})] \\
\text { (median) }\end{array}$ & $\begin{array}{l}\text { HEALTHY POPU- } \\
\text { LATION [mean } \pm \\
\text { SD (CI)] (median) }\end{array}$ & t- Test & $p$ value \\
\hline $\begin{array}{l}\text { Serum } \\
\text { Malo- } \\
\text { ndialdehyde } \\
\text { (nmol/ml) }\end{array}$ & $\begin{array}{c}7.99 \pm 2.31 \\
(7.47-8.49)(7.69)\end{array}$ & $\begin{array}{l}6.13 \pm 1.24 \\
(5.86-6.41) \\
(6.07)\end{array}$ & 6.335 & $<0.001$ \\
\hline $\begin{array}{l}\text { Serum } \\
\text { vitamin C } \\
(\mathrm{mg} / \mathrm{dl})\end{array}$ & $\begin{array}{c}0.65 \pm 0.15 \\
(0.61-0.68)(0.62)\end{array}$ & $\begin{array}{l}0.63 \pm 0.14 \\
(0.59-0.66) \\
(0.59)\end{array}$ & 0.892 & 0.373 \\
\hline $\begin{array}{l}\text { Serum } \\
\text { vitamin } E \\
(\mathrm{mg} / \mathrm{dl})\end{array}$ & $\begin{array}{c}0.67 \pm 0.22 \\
(0.62-0.72)(0.65)\end{array}$ & $\begin{array}{l}0.66 \pm 0.15 \\
(0.63-0.69) \\
(0.66)\end{array}$ & 0.227 & 0.821 \\
\hline $\begin{array}{l}\text { Catalase } \\
\text { (IU/gm Hb) }\end{array}$ & $\begin{array}{c}53.93 \pm 24.77 \\
(48.41-59.44) \\
(47.17)\end{array}$ & $\begin{array}{l}65.83 \pm 18.32 \\
(61.75-69.91) \\
(65.71)\end{array}$ & -3.456 & 0.001 \\
\hline
\end{tabular}

$65.83 \pm 18.32 \mathrm{IU} / \mathrm{gm} \mathrm{Hb}$ respectively. CAT level was found to be significantly lower among the vitiligo patients when compared to the healthy population $(p=0.001)$. Based on the comparison of oxidant-antioxidant status between healthy controls and, stable and progressive vitiligo patients, a significant difference was observed in the levels of MDA and CAT however, no significant difference was found in the levels of vitamin $C$ and vitamin $E$. While on comparing the patients with stable vitiligo and progressive vitiligo no difference was observed in the levels of MDA, CAT, vitamin C and vitamin E (Table 2). In our study, no relation was observed between the oxidant-antioxidants (MDA, CAT, vitamin C, vitamin E) with the skin photo-type, duration of the disease and body surface area involvement.

Table 2. Comparison of oxidant- antioxidant status among table, progressive vitiligo patients and healthy controls

\begin{tabular}{|c|c|c|c|c|c|}
\hline $\begin{array}{l}\text { PA- } \\
\text { RAM- } \\
\text { ETERS }\end{array}$ & $\begin{array}{c}\text { CONTROLS } \\
(n=80) \\
{\left[\begin{array}{c}\text { mean } \pm S D(C I)] \\
\text { (median) }\end{array}\right.}\end{array}$ & $\begin{array}{c}\text { STABLE }(n=11) \\
\text { [mean } \pm \text { SD }(C I)] \\
\text { (median) }\end{array}$ & $\begin{array}{c}\text { PROGRES- } \\
\text { SIVE }(n=69) \\
{[\text { mean } \pm S D(C I)]} \\
\text { (median) }\end{array}$ & F- test & $\begin{array}{c}\mathrm{p}- \\
\text { value }\end{array}$ \\
\hline $\begin{array}{l}\text { Se- } \\
\text { rum } \\
\text { Malo- } \\
\text { ndi- } \\
\text { alde- } \\
\text { hyde } \\
\text { (nmol } \\
\text { /ml) }\end{array}$ & $\begin{array}{l}6.13 \pm 1.24 \\
(5.86-6.41) \\
(6.07)\end{array}$ & $\begin{array}{c}7.55 \pm 1.89 \\
(6.28-8.82) \\
(7.04)\end{array}$ & $\begin{array}{l}8.05 \pm 2.37 \\
(7.49-8.62) \\
(7.77)\end{array}$ & 20.381 & $<0.001$ \\
\hline $\begin{array}{l}\text { Se- } \\
\text { rum } \\
\text { vita- } \\
\text { min C } \\
\text { (mg/ } \\
\text { dl) }\end{array}$ & $\begin{array}{l}0.63 \pm 0.14 \\
(0.59-0.66) \\
(0.59)\end{array}$ & $\begin{array}{c}0.66 \pm 0.15 \\
(0.56-0.76) \\
(0.65)\end{array}$ & $\begin{array}{l}0.65 \pm 0.15 \\
(0.61-0.68) \\
(0.61)\end{array}$ & 0.423 & 0.656 \\
\hline $\begin{array}{l}\text { Se- } \\
\text { rum } \\
\text { vita- } \\
\text { min E } \\
\text { (mg/ } \\
\text { dl) }\end{array}$ & $\begin{array}{l}0.66 \pm 0.15 \\
(0.63-0.69) \\
(0.66)\end{array}$ & $\begin{array}{c}0.63 \pm 0.25 \\
(0.46-0.79) \\
(0.58)\end{array}$ & $\begin{array}{l}0.68 \pm 0.22 \\
(0.62-0.73) \\
(0.65)\end{array}$ & 0.305 & 0.738 \\
\hline $\begin{array}{l}\text { Cata- } \\
\text { lase } \\
\text { (IU/ } \\
\text { gm } \\
\mathrm{Hb} \text { ) }\end{array}$ & $\begin{array}{l}65.83 \pm 18.32 \\
(61.75-69.91) \\
(65.71)\end{array}$ & $\begin{array}{c}51.07 \pm 13.83 \\
(41.78-60.36) \\
(48.67)\end{array}$ & $\begin{array}{l}54.38 \pm 26.14 \\
(48.10-60.66) \\
(46.93)\end{array}$ & 6.050 & 0.003 \\
\hline
\end{tabular}

\section{DISCUSSION}

One of the hypotheses to explain vitiligo is the selfdestructive theory of melanocytes, which suggests a role of oxidative stress. In normal conditions, superoxide dismutase (SOD), an antioxidant enzyme catalyzes the dismutation of superoxide anion $\left(\mathrm{O}_{2}^{-}\right)$into oxygen $\left(\mathrm{O}_{2}\right)$ and hydrogen peroxide $\left(\mathrm{H}_{2} \mathrm{O}_{2}\right)$ and CAT converts $\mathrm{H}_{2} \mathrm{O}_{2}$ to $\mathrm{O}_{2}$ and water $\left(\mathrm{H}_{2} \mathrm{O}\right)$. In oxidative stress, there is insufficient antioxidant activity to counteract or scavenge increased levels of free radicals superoxide anions $\left(\mathrm{O}_{2}^{-}\right)$, SOD is increased, whereas CAT levels are decreased. ${ }^{16}$ Thus, hydrogen peroxide produced from superoxide anion $\left(\mathrm{O}_{2}{ }^{-}\right)$can readily cross cell membranes causing much of the damage to cellular compounds such as protein, carbohydrate, DNA and lipids. ${ }^{6}$

The vitiligo melanocytes are the theatre of the redox balance loss because of the high toxic metabolites or free radical level, or because of a defective antioxidant pattern. ${ }^{17}$ Melanocytes from normally pigmented skin of vitiligo patients exhibit a high in vitro susceptibility to chemical and physical oxidative stress, ${ }^{18}$ which seems to be correlated to an imbalance of intracellular antioxidants. ${ }^{18,19}$ In a recent study conducted among the vitiligo patients, it was observed that the mean serum total antioxidant status (TAS) level in the patient group was significantly lower than in the control group. ${ }^{20}$

Oxidative destruction of polyunsaturated fatty acid (PUFA) of phospholipids known as lipid peroxidation can be considered as a hallmark of the oxidative stress. MDA, an end product of lipid peroxidation induced by reactive oxygen species (ROS), is well correlated with degree of lipid peroxidation. In our study malondialdehyde (MDA) level was significantly higher among the vitiligo patients as compared to healthy population. This finding supports the observation by others. ${ }^{3,7,21}$ However the levels of oxidants and antioxidants have not been investigated in lesional skin of vitiligo patients in our study, Yildirim et al studied in tissue as well as in sera and had found the MDA levels in the skin of vitiligo patients to be higher than the controls and the difference was statistically significant. ${ }^{7}$

Vitamin C is a water-soluble, chain breaking antioxidant. As an antioxidant, it scavenges free radicals and reactive oxygen molecules by donating its electrons to prevent other compounds from being oxidized. ${ }^{22}$ However controversies exist regarding serum ascorbic acid measurement in vitiligo, a few studies have found lower serum ascorbic acid in vitiligo patients than the control. ${ }^{23,24}$ According to the general Ayurvedic system of medicine in India, citrus fruits may worsen the condition. In the present study there was no difference in the value of vitamin $\mathrm{C}$ among the vitiligo patients and the healthy population.

Alpha-tocopherol is an efficient scavenger of lipid peroxyl radicals and, hence, it is able to break peroxyl chain propagation reactions. The unpaired electron of the tocopheroxyl radical thus formed tends to be delocalised rendering the radical more stable. Vitamin $E$ forms 
complexes with the lysophospholipids and free fatty acids liberated by the action of membrane lipid hydrolysis. Both these products form 1:1 stoichiometric complexes with vitamin $\mathrm{E}$ and as a consequence the overall balance of hydrophobic: hydrophilic affinity within the membrane is restored. In this way, vitamin E is thought to negate the detergent-like properties of the hydrolytic products that would otherwise disrupt membrane stability. ${ }^{25}$ The value of vitamin $E$ was $0.67 \pm 0.22 \mathrm{mg} / \mathrm{dl}$ and $0.67 \pm 0.15$ $\mathrm{mg} / \mathrm{dl}$ among the vitiligo patients and healthy population respectively in the present study. The difference between the two groups was not found to be significant with a $p$ value of 0.821 . However Passi et al and Khan et al found significantly lower levels of Vitamin E among active vitiligo patients as compared to the controls. ${ }^{24,26}$

In the present study, the value of catalase (CAT) was found to be significantly lower among the vitiligo patients when compared to healthy population. This decrease in CAT levels among vitiligo patients could be due to the increased oxidative stress among them as compared to the healthy population. This finding was in accordance to the findings of Arican and Kurutas where erythrocyte CAT level was found to be significantly lower than controls. ${ }^{9}$ Sravani et al also found level of CAT to be significantly lower among the skin of vitiligo patients as compared to the healthy populations however Hazneci et al did not find difference between the erythrocyte CAT levels among the vitiligo patients and healthy contro. ${ }^{6,27}$ A study on the catalase gene and its mutations leading to quantitative deficiency of CAT activity in the epidermis and accumulation of excess $\mathrm{H}_{2} \mathrm{O}_{2}$ and susceptibility to develop vitiligo has been reported. ${ }^{28}$

Notably, CAT and SOD, acting in concert with glutathione peroxidase (GPx), constitute the major defense or primary antioxidant enzymes against super-oxide radicals. In vitiligo, varying results have been found in different studies associated with SOD and GPx activities. ${ }^{29}$ It has been proposed that as melanin itself has an antioxidant action, its absence or presence could cause an increased or diminished need for SOD or, overproduction of superoxide anion could provoke the higher SOD activity in the tissue. ${ }^{30}$ However, we have not assessed the serum level of SOD in our study because of unavaibility of this test. The benefit of measurement of catalase is to determine $\mathrm{H}_{2} \mathrm{O}_{2}$ decomposition rate (catalase activity), which is convenient and determine catalase activity in minutes in RBC lysate \& tissue homogenates.

The limitation of the study was that the assessment was limited to the use of blood samples only. Further work is needed to determine if such changes adequately reflect changes both in the sera and lesional skin of the vitiligo patients or changes in peripheral blood is sufficient to represent the oxidative stress.

\section{CONCLUSION}

In conclusion, our findings demonstrate that there has been increased oxidative stress in vitiligo patients, as indicated by increased MDA and decreased CAT levels. These findings further support the associations between oxidative stress and free radical mediated destruction of melanocytes or dysregulation of melanogenesis in the pathogenesis of vitiigo. Further studies might verify the beneficial effect of antioxidant treatment/supplement in patients with vitiligo. We express our sincere gratitude to DD Baral for helping in statistical analysis.

\section{REFERENCES}

1. Ortonne JP, Bahodoran P, Fitzpatrick TB, Mosher DB, Hori Y. Hypomelanoses and Hypermelanoses. In: Freedberg IM, Eisen AZ, Wolff K, Austen KF, Goldsmith LA, Katz SI editors. Fitzpatrick's Dermatology in General Medicine. $6^{\text {th }}$ ed. New York: McGraw Hill 2003: 839- 47.

2. Halder RMMD, Nootheti PKMD. Ethnic skin disorders overview. [miscellaneous] J Am Acad Dermatol 2003; 48(6):S143-8.

3. Oztruk IC, Batcioglu K, Karatas F, Hazneci E, Genc M. Comparison of plasma malondialdehyde, glutathione, glutathione peroxidise, hydroxyproline and selenium levels in patients with vitiligo and healthy controls. Ind J Dermatol 2008;53(3):106-10.

4. Gawkrodger DJ, Ormerod AD, Shaw L, Mauri-Sole I, Whitton ME, Watts MJ et al. Guidelines for the diagnosis and management of vitiligo. Br J Dermatol 2008;159(5):1051-76.

5. Boissy RE, Spritz RA. Frontiers and controversies in the pathobiology of vitiligo: separating the wheat from the chaff. Exp Dermatol 2009;18(7):583-5.

6. Sravani PV, Babu NK, Gopal KV, Rao GR, Rao AR, Moorthy B et al. Determination of oxidative stress in vitiligo by measuring superoxide dismutase and catalase levels in vitiliginous and non-vitiliginous skin. Ind I Dermatol Venereol Leprol 2009;75(3):268-71.

7. Yildrim M, Baysal V, Inaloz HS, Kesici D, Delibas N. The role of oxidants and antioxidants in generalized vitiligo. J Dermatol 2003;30(2):104-8.

8. Ines D, Sonia B, Riadh BM, Amel el G, Slaheddine M, Hamida T et al. A comparative study of oxidant-antioxidant status in stable and active vitiligo patients. Arch Dermatol Res 2006;298(4):147-52.

9. Arican O, Kurutas EB. Oxidative stress in the blood of patients with active localized vitiligo. Acta Dermatovenerol Alp Panonica Adriat 2008;17(1):12-6

10. Jain D, Misra R, Kumar A, Jaiswal G. Levels of malondialdehyde and antioxidants in the blood of patients with vitiligo of age group 11-20 year. Ind J Physiol Pharmacol 2008;52(3):297-301.

11. Shin JW, Nam KM, Choi HR, Huh SY, Kim SW, Youn SW et al. Erythrocyte Malondialdehyde and Glutathione Levels in vitiligo Patients. Ann Dermatol 2010;22(3): 279-83.

12. Yagi K. Lipid peroxides and human diseases. Chem Phys Lipids 1987;45(2-4):337-51.

13. Sullivan MX, Clarke HCN. Estimation of Ascorbic Acid. J Assoc Agric Chem 1955;38:514 -5.

14. Bieri JG, Teets I, Belavculy B, Andrews EL. Serum Vitamin E levels in a normal adult population in Washington DC Area. Proc Soc Exp Biol Med 1964;117:131-3.

15. Sinha AK. Colorimeter assay of catalase. Anal Biochem 1972;47(2):389-94. 
16. Sichak SP, Dounce AL. Analysis of the peroxidatic mode of action of catalase. Arch Biochem Biophys 1986; 249(2):286-95.

17. Haycock JW, Rowe SJ, Cartledge S, Wyatt A, Ghanem G, Morandini $R$ et al. $\alpha$-Melanocyte-stimulating hormone reduces impact of proinflammatory cytokine and peroxide-generated oxidative stress on keratinocytes and melanoma cell lines. J Biol Chem 2000;275(21): 15629-36.

18. Maresca V, Roccella M, Roccella F, Camera E, Del Porto G, Passi $S$ et al. Increased sensitivity to peroxidative agents as possible pathogenic factor of melanocyte damage in vitiligo. J Invest Dermatol 1997;109(3):310-3.

19. Agrawal D, Shajil EM, Marfatia YS, Begum R. Study on the Antioxidant Status of Vitligo Patients of Different Age Groups in Baroda. Pigment Cell Res 2004;17(3): 289 -94.

20. Singh S, Singh $U$, Pandey SS. Study of total antioxidants status in Indian Vitiligo patients. Egyptian Dermatol Online J 2011; 7(1): 2.

21. Mehaney DA, Darwish HA, Hegazy RA, Nooh MM, Tawdy AM, Gawdat $\mathrm{HI}$, El-Sawalhi MM. Analysis of oxidative stress status, catalase and catechol-O-methyltransferase polymorphisms in Egyptian vitiligo patients. PLoS One 2014 Jun 10; 9(6):e99286.

22. Padayatty SJ, Katz A, Wang Y, Eck P, Kwon O, Lee JH et al. Vitamin C as an antioxidant: evaluation of its role in disease prevention. J Am Coll Nutr 2003;22:18-35.
23. Montes LF, Diaz ML, Lajous J, Garcia NJ. Folic acid and vitamin B12 in vitiligo: a nutritional approach. Cutis 1992; 50:39-42.

24. Khan R, Satyam A, Gupta S, Sharma VK, Sharma A. Circulatory levels of antioxidants and lipid peroxidation in Indian patients with generalized and localized vitiligo. Arch Dermatol Res 2009; 301:731-7.

25. Wang X, Quinn PJ. Vitamin E and its function in membranes. Prog Lipid Res 1999; 38(4): 309- 36.

26. Passi S, Grandinetti M, Maggio F, Stancato A, De Luca C. Epidermal Oxidative Stress in Vitiligo. Pigment Cell Res 1998; 11(2): 81-5.

27. Hazneci E, Karabulut AB, Oztürk C, Batçioğ lu K, Doğan G, Karaca S et al. A comparative study of superoxide dismutase, catalase, and glutathione peroxidase activities and nitrate levels in vitiligo patients. Int J Dermatol 2005; 44(8): 636-40.

28. Casp CB, She JX, McCormack WT. Genetic association of the catalase gene (CAT) with vitiligo susceptibility. Pigment Cell Res 2002;15: 62-6.

29. Nabil K, Nagat S, Hanan K, Mai I. A comparative study of oxidantantioxidant status in blood and tissue in vitiligo patients. EDOJ 2010; 6 (2): 1-10.

30. Chakraborty DP, Roy S, Chakraborty AK. Genetic association of the catalase gene (CAT) with vitiligo susceptibility. Pigment cell Res 1996; 141:301-3. 